\title{
Cellulomonas phragmiteti sp. nov., a cellulolytic bacterium isolated from reed (Phragmites australis) periphyton in a shallow soda pond
}

Correspondence

Anna Rusznyák

anna.rusznyak@gmail.com

\author{
Anna Rusznyák, ${ }^{1} \dagger$ Erika M. Tóth, ${ }^{1}$ Peter Schumann, ${ }^{2}$ Cathrin Spröer, ${ }^{2}$ \\ Judit Makk, ${ }^{1}$ Gitta Szabó, ${ }^{1}$ Péter Vladár, ${ }^{1}$ Károly Márialigeti ${ }^{1}$ \\ and Andrea K. Borsodi ${ }^{1}$ Hungary
${ }^{2}$ DSMZ-German Collection of Microorganisms and Cell Cultures, Inhoffenstrasse 7B, D-38124 Braunschweig, Germany \\ 1Department of Microbiology, Eötvös Loránd University, Pázmány P. sétány 1/C H-1117 Budapest,
}

\begin{abstract}
An alkalitolerant and moderately halophilic strain, designated $\mathrm{KB}^{2} 3^{\top}$, characterized by optimal growth at $\mathrm{pH} 8.0-9.0$ and in the presence of $5-7 \%(\mathrm{w} / \mathrm{v}) \mathrm{NaCl}$, was isolated from a reed (Phragmites australis) periphyton sample originating from an extremely shallow, alkaline soda pond located in Hungary. Cells of strain $\mathrm{KB}^{2} 3^{\top}$ were Gram-stain-positive, motile straight rods. Strain $\mathrm{KB} 23^{\top}$ was facultatively anaerobic, catalase-positive, oxidase-negative and contained peptidoglycan type $\mathrm{A} 4 \beta$ (L-Orn-D-Asp). MK- $9(\mathrm{H} 4)$ was the predominant isoprenoid quinone and anteiso- $\mathrm{C}_{15: 0}, \mathrm{C}_{16: 0}$ and anteiso- $\mathrm{C}_{15: 1}$ were the major cellular fatty acids. The DNA G+C content of strain KB23 ${ }^{\top}$ was 74.8 mol\%. Phylogenetic analysis based on $16 \mathrm{~S}$ rRNA gene sequences showed that this strain belongs to the genus Cellulomonas and that it is related most closely to Cellulomonas flavigena DSM $20109^{\top}$ (97.35\% similarity), Cellulomonas terrae DB5 ${ }^{\top}$ (96.81\%), Cellulomonas iranensis $\mathrm{O}^{\top}$ (96.75), Cellulomonas chitinilytica X.bu-b ${ }^{\top}(96.60 \%)$, Cellulomonas persica I $\mathrm{I}^{\top}(96.53 \%)$, Cellulomonas composti TR7-06 ${ }^{\top}(96.45 \%)$, Cellulomonas biazotea DSM $20112^{\top}$ (96.34\%) and Cellulomonas fimi DSM $20113^{\top}$ (96.20\%). According to these results, together with DNA-DNA hybridization and physiological data, strain $\mathrm{KB}^{2} 3^{\top}$ is considered to represent a novel species of the genus Cellulomonas, for which the name Cellulomonas phragmiteti sp. nov. is proposed. The type strain is KB23 ${ }^{\top}$ (=DSM $22512^{\top}$ $=$ NCAIM B002303 ${ }^{\top}$ ).
\end{abstract}

Soda lakes and ponds are characterized by very high productivity as well as high levels of activity of the various decomposition processes which take place (Grant et al., 1990). Bacteria isolated from such environments show considerable phylogenetic and physiological diversity (Zavarzin et al., 1999; Jones et al., 1998; Duckworth et al., 1996; Zhilina \& Zavarzin, 1994). Much of the physiological diversity of these bacteria is based on their disposal of various enzymes, influencing the efficiency of self-purification processes, including the degradation of

tPresent address: Friedrich Schiller University, Institute of Ecology, Limnology/Aquatic Geomicrobiology Group, Dornburger Str. 159, 07743 Jena, Germany.

The GenBank/EMBL/DDBJ accession number for the 16S rRNA gene sequence of strain $\mathrm{KB}^{\mathrm{T}}{ }^{\top}$ is $\mathrm{AM} 902253$.

Two supplementary figures are available with the online version of this paper. autochthonous and allochthonous organic matter in aquatic environments.

During a polyphasic study of plant-associated bacterial communities, a large number of bacterial strains were isolated (Rusznyák et al., 2008) from reed periphyton originating from a shallow soda pond (Kelemen-szék, Kiskunság National Park, Hungary, $46^{\circ} 47^{\prime} \mathrm{N} 19^{\circ} 11^{\prime} \mathrm{E}$ ) in April 2004. Conductivity and $\mathrm{pH}$ of the pond water at the time of sampling were $1960 \mu \mathrm{S} \mathrm{cm}^{-1}$ and $\mathrm{pH}$ 9.1. On the basis of preliminary $16 \mathrm{~S}$ rRNA gene sequence data, one strain, designated $\mathrm{KB} 23^{\mathrm{T}}$, was found to be a member of the genus Cellulomonas in the suborder Micrococcineae, being able to digest cellulose. The aim of this study was to determine the taxonomic position of strain $\mathrm{KB} 23^{\mathrm{T}}$. Further study of this strain, based on a polyphasic approach that included chemotaxonomic, physiological and DNA-DNA hybridization analyses, confirmed its taxonomic position as a representative of a novel species within the genus Cellulomonas. 
From the sampling site, 10-cm-long reed (Phragmites australis) stem pieces were collected in five replicates from about $10-20 \mathrm{~cm}$ below the water surface. Biofilm samples were washed from the reed stems into sterile saline solution ( $\left.0.89 \mathrm{~g} \mathrm{NaCl}^{-1}, \mathrm{pH} 9\right)$ by using sterile brushes. Cultivation was from composite samples prepared from aliquots of the sample and serial dilutions were made. Strain $\mathrm{KB} 23^{\mathrm{T}}$ was isolated on King's B medium (Barrow \& Feltham, 2003), adjusted to $\mathrm{pH} 9$, following a 7 day incubation period at $25{ }^{\circ} \mathrm{C}$ under aerobic conditions. After isolation, strain $\mathrm{KB} 23^{\mathrm{T}}$ was cultivated by being transferred monthly onto King's B medium. Stock cultures were preserved as suspensions in glycerol $(20 \%, \mathrm{v} / \mathrm{v})$ at $-70{ }^{\circ} \mathrm{C}$.

Colony morphology as well as cell morphology of Hucker's Gram-stained smears was observed. Motility of cells was examined in wet-mount preparations by phase-contrast microscopy. Standard biochemical tests were performed (catalase and oxidase reactions, oxidative and fermentative utilization of D-glucose, nitrate reduction, methyl red and Voges-Proskauer reaction, Simmon's citrate test, BairdParker's phosphatase activity, aesculin, casein, gelatin, starch, Tween 80 and DNA hydrolysis, hydrogen sulphide and indole production) according to Barrow \& Feltham (2003). Hydrolysis of cellulose was tested according to Horikoshi (1995). Other physiological and biochemical properties were further determined with API ZYM and API $50 \mathrm{CH}$ test kits (bioMérieux) according to the manufacturer's instructions. The $\mathrm{pH}$ range for growth was determined in nutrient broth (DSMZ Medium 1, www. dsmz.de) (supplemented with $50 \mathrm{~g} \mathrm{NaCl} \mathrm{l}^{-1}$ ) for 7 days that was adjusted to $\mathrm{pH} 7.0-11.0$ with $\mathrm{KOH}$ at intervals of $1.0 \mathrm{pH}$ unit. The $\mathrm{NaCl}$ requirement for growth was studied in nutrient broth adjusted to $\mathrm{pH} 9.0$ and supplemented with $0,2.0,5.0,7.0,10.0$ and $12.0 \%(\mathrm{w} / \mathrm{v}) \mathrm{NaCl}$ for 7 days. Optical density alterations were observed at $600 \mathrm{~nm}$ over 1-7 days. Growth under anaerobic conditions was determined after incubating the strain on King's $\mathrm{B}$ agar in a GasPak jar (BBL) at $25{ }^{\circ} \mathrm{C}$ for 7 days. Cellulomonas flavigena DSM $20109^{\mathrm{T}}$ was used as reference strain for the investigation of phenotypic properties of strain $\mathrm{KB} 23^{\mathrm{T}}$ under the same laboratory conditions.

Isolation of chromosomal DNA, PCR amplification and direct sequencing of the purified product were carried out as described previously (Rusznyák et al., 2008). The complete 16S rRNA gene sequence of strain $\mathrm{KB}^{2} 3^{\mathrm{T}}$ was assembled by using the BioEdit program (Hall, 1999). The $16 \mathrm{~S}$ rRNA gene sequences of related taxa were obtained from the GenBank database. Multiple alignments were performed by using the CLUSTAL $\mathrm{x}$ program (Thompson et al., 1997). Evolutionary distances were calculated by using Kimura's two-parameter model (Kimura, 1983) and the Jukes-Cantor model (Jukes \& Cantor, 1969). Phylogenetic trees were reconstructed by using the neighbour-joining (Saitou \& Nei, 1987) and minimumevolution (Fitch, 1971) methods in the MEGA4 program (Tamura et al., 2007), with bootstrap values based on 2000 replications (Felsenstein, 1985). The neighbour-joining phylogenetic tree with Kimura's two-parameter model is shown in Fig. 1. Phylogenetic trees reconstructed with additional models are presented in Supplementary Fig. S1 available in IJSEM Online.

The peptidoglycan of strain $\mathrm{KB} 23^{\mathrm{T}}$ was isolated after disintegration of cells with glass beads in a Vibrogen cell mill (Johanna Otto $\mathrm{GmbH}$ ) and subsequent trypsin digestion according to the method of Schleifer \& Seidl (1985), and its structure was analysed by using the methods of Schleifer (1985), MacKenzie (1987) and Groth et al. (1996). For analysis of cell-wall sugars, the peptidoglycan preparation was hydrolysed in $0.5 \mathrm{M} \mathrm{H}_{2} \mathrm{SO}_{4}\left(2 \mathrm{~h}\right.$ at $\left.100{ }^{\circ} \mathrm{C}\right)$. $\mathrm{H}_{2} \mathrm{SO}_{4}$ was removed by $20 \%(N, N)$-dioctylmethylamine in chloroform according to Whiton et al. (1985) and the sugars in the hydrolysate were analysed by TLC on cellulose plates according to Staneck \& Roberts (1974). Isoprenoid quinones were extracted from cells cultivated in liquid Rich medium (Yamada \& Komagata, 1972) according to the method of Collins et al. (1977) and the profile was analysed by HPLC (HP 9001) (Groth et al., 1997). Cellular fatty acids were extracted from cells cultivated on trypticase soy agar (Difco) at $28{ }^{\circ} \mathrm{C}$ according to Stead et al. (1992) and were analysed by GC (Groth et al., 1996).

The $\mathrm{G}+\mathrm{C}$ content of the chromosomal DNA was determined as described by Mesbah et al. (1989) by using reversed-phase HPLC (Shimadzu). For spectroscopic DNA-DNA hybridization, DNA was isolated with a French pressure cell (Thermo Spectronic) and was purified by chromatography on hydroxyapatite as described by Cashion et al. (1977). DNA-DNA hybridizations were carried out as described by De Ley et al. (1970) under consideration of the modifications described by Huß et al. (1983) by using a model Cary 100 Bio UV/VIS-spectrophotometer equipped with a Peltier-thermostatted $6 \times 6$ multicell changer and a temperature controller with in-situ temperature probe (Varian).

Strain $\mathrm{KB} 23^{\mathrm{T}}$ was facultatively anaerobic. Cells stained Gram-positive, were rod-shaped $(0.4-0.6 \times 1.0-1.5 \mu \mathrm{m})$, motile and did not form a mycelium. Strain $\mathrm{KB}^{\mathrm{T}}{ }^{\mathrm{T}}$ contained L-Orn-D-Asp as an interpeptide bridge in the peptidoglycan (type A4 $\beta$; DSMZ type A21.4, http://www. dsmz.de/microorganisms/main.php?content_id=35). The predominant quinone was MK-9(H4). The sugars analysed in the purified cell wall were rhamnose, mannose and fucose. The DNA G+C content of strain $\mathrm{KB}_{2} 3^{\mathrm{T}}$ was $74.8 \mathrm{~mol} \%$.

High levels of $16 \mathrm{~S}$ rRNA gene sequence similarity between the type strains of recognized species of the genus Cellulomonas and strain $\mathrm{KB}^{2} 3^{\mathrm{T}}$ (almost-complete $16 \mathrm{~S}$ rRNA gene sequence, $1413 \mathrm{bp}$ ) supported its inclusion in the genus Cellulomonas. It was evident from Fig. 1 that strain $\mathrm{KB} 23^{\mathrm{T}}$ was related most closely to C. flavigena DSM $20109^{\mathrm{T}}(97.35 \%$ 16S rRNA gene sequence similarity), supported by a high bootstrap value. However, it was evident from DNA-DNA hybridization data that strain $\mathrm{KB}^{2} 3^{\mathrm{T}}$ and C. flavigena DSM $20109^{\mathrm{T}}$ should not be 


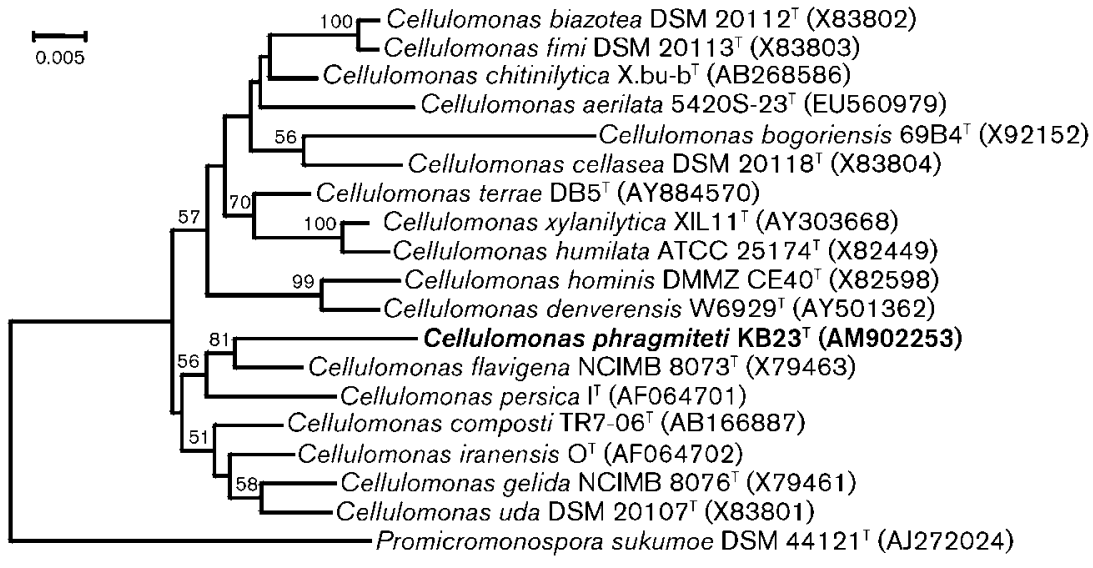

Fig. 1. Neighbour-joining phylogenetic tree based on almost-complete 16S rRNA gene sequences showing the relationships between strain $\mathrm{KB} 3^{\top}$ and representatives of the genus Cellulomonas. Numbers at nodes indicate levels of bootstrap support (percentages) based on a neighbour-joining analysis of 2000 resampled datasets; only values $>50 \%$ are shown. Bar, 0.005 substitutions per nucleotide site. classified within the same species as they shared a DNADNA hybridization value of $18.5 \%$ [repetition $23.1 \%$; in $2 \times$ standard saline citrate buffer with $10 \% \quad(\mathrm{v} / \mathrm{v})$ formamide at $71{ }^{\circ} \mathrm{C}$ ], well below the $70 \%$ cut-off point recommended for the delineation of genomic species (Wayne et al., 1987). The organism also had a profile of phenotypic properties that distinguished it from the type strains of recognized species of the genus Cellulomonas (Yoon et al., 2008; Kang et al., 2007; An et al., 2005). Additionally, a number of characteristics distinguished strain $\mathrm{KB} 23^{\mathrm{T}}$ from C. flavigena, for example methyl-red reaction, nitrate reduction, hydrolysis of urea, casein and Tween 80 , and activities of a number of enzymes (Table 1). Furthermore, strain $\mathrm{KB} 23^{\mathrm{T}}$ was capable of utilizing a number of carbon sources in contrast to the type strain of C. flavigena (Table 1).

The genotypic and phenotypic data indicate that strain $\mathrm{KB} 23^{\mathrm{T}}$ merits recognition as a representative of a novel species of the genus Cellulomonas, for which the name Cellulomonas phragmiteti sp. nov. is proposed.

\section{Description of Cellulomonas phragmiteti sp. nov.}

Cellulomonas phragmiteti (phrag.mi'te.ti. N.L. gen. n. phragmiteti of Phragmitetum, referring to plant association Scirpo-Phragmitetum, the habitat from where the type strain was isolated).

Cells are Gram-stain-positive, facultatively anaerobic, motile rods. Colonies on King's B agar plates are, smooth, yellow to pale orange and circular within 3 days at $25{ }^{\circ} \mathrm{C}$. Catalase-positive and oxidase-negative. Growth occurs at $15-37{ }^{\circ} \mathrm{C}$, at $\mathrm{pH} 7.0-9.0$ and in the presence of $2.0-7.0 \%$ (w/v) $\mathrm{NaCl}$. Optimum growth occurs at $25{ }^{\circ} \mathrm{C}$, at $\mathrm{pH} 8.0$ and with $5.0 \%(\mathrm{w} / \mathrm{v}) \mathrm{NaCl}$. Growth occurs under anaerobic conditions on King's B agar. Utilizes L-arabinose, $\mathrm{D}$-xylose, methyl $\beta$-D-xylopyranoside, D-galactose, D-glucose, D-fructose, D-mannose, D-mannitol, arbutin, aesculin, salicin, cellobiose, maltose, melibiose, sucrose, trehalose, melezitose, starch, glycogen and turanose as sole carbon source, but not glycerol, erythritol, D-arabinose, D-ribose, L-xylose, D-adonitol, L-sorbose, L-rhamnose, dulcitol, inositol, D-sorbitol, methyl $\alpha$-D-mannopyranoside, methyl $\alpha$-D-glucopyranoside, $N$-acetylglucosamine, amygdalin, lactose, inulin, raffinose, xylitol, gentiobiose, D-lyxose, Dtagatose, D-fucose, L-fucose, D-arabitol, L-arabitol, potassium gluconate, potassium 2-ketogluconate or potassium 5-ketogluconate. Hydrolyses casein, gelatin, aesculin and Tween 80. Cellulase is produced. Does not produce indole from tryptophan or hydrogen sulphide from cysteine.

Table 1. Differential characteristics between strain $\mathrm{KB}^{2} 3^{\top}$ and its nearest phylogenetic neighbour, Cellulomonas flavigena DSM $20109^{\top}$

Strains: $1, \mathrm{~KB} 23^{\mathrm{T}} ; 2$, C. flavigena DSM $20109^{\mathrm{T}}$. All data are from the present study.

\begin{tabular}{|c|c|c|}
\hline Characteristic & 1 & 2 \\
\hline Colony colour & $\begin{array}{c}\text { Yellow- } \\
\text { orange }\end{array}$ & Yellow \\
\hline Motility & + & - \\
\hline Methyl-red test & + & - \\
\hline Reduction of nitrate to nitrite & - & + \\
\hline \multicolumn{3}{|l|}{ Hydrolysis of: } \\
\hline Urea & + & - \\
\hline Tween 80 & + & - \\
\hline Casein & + & - \\
\hline \multicolumn{3}{|l|}{ Enzyme activities } \\
\hline Esterase lipase (C8) & + & - \\
\hline Valine arylamidase & + & - \\
\hline$\alpha$-Chymotrypsin & - & + \\
\hline Acid phosphatase & - & + \\
\hline $\begin{array}{l}\text { Naphthol-AS-BI- } \\
\text { phosphohydrolase }\end{array}$ & - & + \\
\hline \multicolumn{3}{|l|}{ Carbon source utilization } \\
\hline Methyl $\beta$-D-xylopyranoside & + & - \\
\hline D-Mannitol & + & - \\
\hline Arbutin & + & - \\
\hline Melibiose & + & - \\
\hline Trehalose & + & - \\
\hline Melezitose & + & - \\
\hline Turanose & + & - \\
\hline
\end{tabular}


Table 2. Fatty acid profiles of strain $\mathrm{KB}_{2} 3^{\top}$ and Cellulomonas flavigena DSM $20109^{\top}$

Data are from the present study. Values are percentages of the total fatty acids.

\begin{tabular}{|c|c|c|}
\hline Fatty acid & $\mathrm{KB} 23^{\mathrm{T}}$ & C. flavigena DSM $20109^{\mathrm{T}}$ \\
\hline $\mathrm{C}_{12: 0}$ & - & 0.12 \\
\hline $\mathrm{C}_{13: 0}$ & 0.34 & 0.35 \\
\hline $\mathrm{C}_{14: 0}$ & 6.85 & 10.17 \\
\hline $\mathrm{C}_{15: 0}$ & 2.05 & - \\
\hline $\mathrm{C}_{16: 0}$ & 23.31 & 20.85 \\
\hline $\mathrm{C}_{17: 0}$ & 0.20 & 0.44 \\
\hline $\mathrm{C}_{18: 0}$ & 0.21 & 0.16 \\
\hline iso- $\mathrm{C}_{14: 0}$ & 1.63 & 3.21 \\
\hline iso- $\mathrm{C}_{15: 0}$ & 2.52 & 3.34 \\
\hline iso- $\mathrm{C}_{16: 0}$ & 1.65 & 3.29 \\
\hline iso- $\mathrm{C}_{17: 0}$ & 0.15 & 0.39 \\
\hline iso- $\mathrm{C}_{15: 1}$ & 0.22 & 0.41 \\
\hline anteiso- $\mathrm{C}_{13: 0}$ & 0.55 & 0.31 \\
\hline anteiso- $\mathrm{C}_{15: 0}$ & 37.83 & 38.92 \\
\hline anteiso- $\mathrm{C}_{17: 0}$ & 3.46 & 3.87 \\
\hline anteiso- $\mathrm{C}_{15: 1}$ & 19.03 & 14.17 \\
\hline
\end{tabular}

Positive in the methyl-red test but negative for the VogesProskauer reaction. Negative for nitrate reduction. Positive for urease but negative for phosphatase. The peptidoglycan is of type $\mathrm{A} 4 \beta$ ( $\mathrm{L}-\mathrm{Orn}-\mathrm{D}-\mathrm{Asp})$. MK-9(H4) is the predominant menaquinone. The major cellular fatty acids are anteiso- $\mathrm{C}_{15: 0}, \mathrm{C}_{16: 0}$ and anteiso- $\mathrm{C}_{15: 1}$ (Table 2). The $\mathrm{G}+\mathrm{C}$ content of the genomic DNA of the type strain is $74.8 \mathrm{~mol} \%$.

The type strain, $\mathrm{KB} 23^{\mathrm{T}} \quad\left(=\mathrm{DSM} \quad 22512^{\mathrm{T}}=\right.$ NCAIM $\mathrm{B} 002303^{\mathrm{T}}$ ), was isolated from Phragmites australis-associated biofilm originating from a soda pond in Kiskunság National Park, Hungary.

\section{Acknowledgements}

This research was supported by the Hungarian Scientific Research Fund (OTKA) Grant T038021. We are indebted to Mrs Anika Wasner and Mrs Bettina Sträubler (both DSMZ) for excellent technical assistance in peptidoglycan analysis and DNA-DNA hybridization, respectively.

\section{References}

An, D. S., Im, W. T., Yang, H. C., Kang, M. S., Kim, K. K., Jin, L., Kim, M. K. \& Lee, S. T. (2005). Cellulomonas terrae sp. nov., a cellulolytic and xylanolytic bacterium isolated from soil. Int J Syst Evol Microbiol 55, 1705-1709.

Barrow, G. I. \& Feltham, R. K. A. (2003). Cowan and Steel's Manual for the Identification of Medical Bacteria. Cambridge: Cambridge University Press.

Cashion, P., Holder-Franklin, M. A., McCully, J. \& Franklin, M. (1977). A rapid method for the base ratio determination of bacterial DNA. Anal Biochem 81, 461-466.
Collins, M. D., Pirouz, T., Goodfellow, M. \& Minnikin, D. E. (1977). Distribution of menaquinones in actinomycetes and corynebacteria. J Gen Microbiol 100, 221-230.

De Ley, J., Cattoir, H. \& Reynaerts, A. (1970). The quantitative measurement of DNA hybridization from renaturation rates. Eur $J$ Biochem 12, 133-142.

Duckworth, A. W., Grant, W. D., Jones, B. E. \& Steenbergen, R. V. (1996). Phylogenetic diversity of soda lake alkaliphiles. FEMS Microbiol Ecol 19, 181-191.

Felsenstein, J. (1985). Confidence limits on phylogenies: an approach using the bootstrap. Evolution 39, 783-791.

Fitch, W. M. (1971). Toward defining the course of evolution: minimum change for a specific tree topology. Syst Zool 20, 406416.

Grant, W. D., Mwatha, W. E. \& Jones, B. E. (1990). Alkaliphiles: ecology, diversity and application. FEMS Microbiol Lett 75, 255269.

Groth, I., Schumann, P., Weiss, N., Martin, K. \& Rainey, F. A. (1996). Agrococcus jenensis gen. nov., sp. nov., a new genus of actinomycetes with diaminobutyric acid in the cell wall. Int J Syst Bacteriol 46, 234-239.

Groth, I., Schumann, P., Rainey, F. A., Martin, K., Schuetze, B. \& Augsten, K. (1997). Demetria terragena gen. nov., sp. nov., a new genus of actinomycetes isolated from compost soil. Int J Syst Bacteriol 47, 1129-1133.

Hall, T. A. (1999). BioEdit: a user-friendly biological sequence alignment editor and analysis program for Windows 95/98/NT. Nucleic Acids Symp Ser 41, 95-98.

Horikoshi, K. (1995). Discovering novel bacteria, with an eye to biotechnological applications. Curr Opin Biotechnol 6, 292-297.

Huß, V. A. R., Festl, H. \& Schleifer, K. H. (1983). Studies on the spectrophotometric determination of DNA hybridization from renaturation rates. Syst Appl Microbiol 4, 184-192.

Jones, B. E., Grant, W. D., Duckworth, A. W. \& Owenson, G. G. (1998). Microbial diversity of soda lakes. Extremophiles 2, 191-200.

Jukes, T. H. \& Cantor, C. R. (1969). Evolution of protein molecules. In Mammalian Protein Metabolism, pp. 21-132. Edited by H. N. Munro. New York: Academic Press.

Kang, M. S., Im, W. T., Jung, H. M., Kim, M. K., Goodfellow, M., Kim, K. K., Yang, H. C., An, D. S. \& Lee, S. T. (2007). Cellulomonas composti sp. nov., a cellulolytic bacterium isolated from cattle farm compost. Int J Syst Evol Microbiol 57, 1256-1260.

Kimura, M. (1983). The Neutral Theory of Molecular Evolution. Cambridge: Cambridge University Press.

MacKenzie, S. L. (1987). Gas chromatographic analysis of amino acids as the $N$-heptafluorobutyryl isobutyl esters. J Assoc Off Anal Chem 70, 151-160.

Mesbah, M., Premachandran, U. \& Whitman, W. B. (1989). Precise measurement of the $\mathrm{G}+\mathrm{C}$ content of deoxyribonucleic acid by highperformance liquid chromatography. Int J Syst Bacteriol 39, 159-167.

Rusznyák, A., Vladár, P., Szabó, G., Márialigeti, K. \& Borsodi, A. K. (2008). Phylogenetic and metabolic bacterial diversity of Phragmites australis periphyton communities in two Hungarian soda ponds. Extremophiles 12, 763-773.

Saitou, N. \& Nei, M. (1987). The neighbor-joining method: a new method for reconstructing phylogenetic trees. Mol Biol Evol 4, 406425.

Schleifer, K. H. (1985). Analysis of the chemical composition and primary structure of murein. Methods Microbiol 18, 123-156.

Schleifer, K. H. \& Seidl, P. H. (1985). Chemical composition and structure of murein. In Chemical Methods in Bacterial Systematics, pp. 
201-215. Edited by G. M. Minnikin \& D. E. Minnikin. London: Academic Press.

Staneck, J. L. \& Roberts, G. D. (1974). Simplified approach to identification of aerobic actinomycetes by thin-layer chromatography. Appl Microbiol 28, 226-231.

Stead, D. E., Sellwood, J. E., Wilson, J. \& Viney, I. (1992). Evaluation of a commercial microbial identification system based on fatty acid profiles for rapid, accurate identification of plant pathogenic bacteria. J Appl Bacteriol 72, 315-321.

Tamura, K., Dudley, J., Nei, M. \& Kumar, S. (2007). MEGA4: molecular evolutionary genetics analysis (MEGA) software version 4.0. Mol Biol Evol 24, 1596-1599.

Thompson, J. D., Gibson, T. J., Plewniak, F., Jeanmougin, F. \& Higgins, D. G. (1997). The CLUSTAL_X windows interface: flexible strategies for multiple sequence alignment aided by quality analysis tools. Nucleic Acids Res 25, 4876-4882.

Wayne, L. G., Brenner, D. J., Colwell, R. R., Grimont, P. A. D., Kandler, O., Krichevsky, M. I., Moore, L. H., Moore, W. E. C., Murray, R. G. E. \& other authors (1987). International Committee on Systematic Bacteriology.
Report of the ad hoc committee on reconciliation of approaches to bacterial systematics. Int J Syst Bacteriol 37, 463-464.

Whiton, R. S., Lau, P., Morgan, S. L., Gilbart, J. \& Fox, A. (1985). Modifications in the alditol acetate method for analysis of muramic acid and other neutral and amino sugars by capillary gas chromatography-mass spectrometry with selected ion monitoring. J Chromatogr A 347, 109-120.

Yamada, K. \& Komagata, K. (1972). Taxonomic studies on coryneform bacteria. IV. Morphological, cultural, biochemical, and physiological characteristics. J Gen Appl Microbiol 18, 399-416.

Yoon, M. H., Ten, L. N., Im, W. T. \& Lee, S. T. (2008). Cellulomonas chitinilytica sp. nov., a chitinolytic bacterium isolated from cattle-farm compost. Int J Syst Evol Microbiol 58, 18781884.

Zavarzin, G. A., Zhilina, T. N. \& Kevbrin, V. V. (1999). The alkaliphilic microbial community and its functional diversity. Mikrobiologiya 68, 579-599 (in Russian).

Zhilina, T. N. \& Zavarzin, G. A. (1994). Alkaliphilic anaerobic community at pH10. Curr Microbiol 29, 109-112. 